\title{
Inserts Coating Influence on Residual Stress of Turned Outer Bearings
}

Marek Kordik ${ }^{1}$, Jozef Struharnansky ${ }^{1}$, Anton Martikan ${ }^{1}$, Dana Stancekova ${ }^{1}$, Sylvia Kusmierczak ${ }^{2}$, Juraj Martinček ${ }^{1}$

${ }^{1}$ University of Zilina, Faculty of Mechanical Engineering, Univerzitna 1, 010 26, Zilina, Slovak Republic, E-mail: mrek.kordik@fstroj.uniza.sk, jozef.struharnansky@fstroj.uniza.sk, anton.martikan@fstroj.uniza.sk, dana.stancekova@fstroj.uniza.sk,

${ }^{2}$ J.E.Purkyně Univerzity, Faculty of Production Technology and Management, Ústí nad Labem, CZ, E-mail: kusmierczak@fvtm.ujep.cz

Residual stresses significantly affect the life of parts material, especially in bearing manufacturing, where the stress introduced into the material in the manufacturing process affect the component throughout its whole operating life. It is therefore important to know the size and orientation of these stresses and to optimize the production process of the bearing rings, in order to eliminate as many of these undesirable stresses. The subject of the article is chosen at demand of practice and has to correlate coating cutting tool for residual stress and microstructure in turning the outer bearing rings made of material 1.3520 , which is widely used in bearing production. Turning cutting tool WNMG 080408E-M was used with two different coatings. We conducted measurements on a X-ray diffractometer. We measured normal stress parameter and the FWHM (full width half maximum at), which is decisive, and it is related to the grain size of the material. We found that the residual axial stress approaching the zero value, depending on the etched layer.

Keywords: residual stresses, bearing rings, coatings, inserts

\section{Acknowledgement}

The article was funded by the grant project VEGA 1/0773/12 - "Implementation of technical ceramic material research to increase the innovation of hybrid products".

\section{References}

[1] KOURIL, K., CEP, R., JANASEK, A.' KRIZ, A.' STANCEKOVA, D. (2014). Surface integrity at reaming operation by MT3 head. Manufacturing Technology, Vol. 14, Issue 2, pp. 193 - 199.

[2] NÁPRSTKOVÁ, N., SVOBODOVÁ, J., CAIS, J. (2013). Influence of strontium in AlSi7Mg0.3 alloy on the tool wear. Manufacturing Technology, Vol. 13, Issue 3, pp. 368-373.

[3] STANCEKOVA, D., KURNAVA, T., SAJGALIK, M., NAPRSTKOVA, N., STRUHARNANSKY, J., ŠČOTKA, P. (2014). Identification of machinability of ceramic materials by turning. Manufacturing Technology, Volume 14, Issue 1, 2014, pp. 91- 97

[4] RUDAWSKA, A., KUCZMASZEWSKI, J. (2006). Surface free energy of zinc coating after finishing treatment. Materials Science- Poland, Vol. 24, Issue 4, pp. 975-981

[5] KUMIČÁKOVÁ, D., GÓRSKI, F., MILECKI, A., GRAJEWSKI, D. (2013). Utilization of advanced simulation methods for solving of assembly processes automation partial tasks. Manufacturing Technology, Vol. 13, Issue 4, pp. $478-486$.

[6] CZÁN, A., MARTIKÁŇ, A., HOLUBJÁK, J., STRUHÁRŇANSKY, J. (2014). Identification of stress and structure properties in surface and subsurface layers of nuclea reactor austenitic steel. Manufacturing Technology. Vol. 14, Issue 3, pp. 276-281

[7] MRAZOVA, M., STANCEKOVA, D., SEMCER, J. (2011) Comparasion of machinability of biocompatible materials used in medicine for dental implants. DAAAM, pp. 1115-1116.

[8] SADÍLEK, M., KRATOCHVÍL, J., PETRŮ, J.,CEP, R., ZLÁMAL, T., STANČEKOVÁ, D. (2014) Cutting tool wear monitoring with the use of impedance layers. Tehnicki Vjesnik, volume 21, 3/2014, pp. 639 - 644.

[9] NESLUŠAN, M., ČILLIKOVÁ, M. (2015). Teoretické základy trieskového obrábania, EDIS, Žilina, 153 s.

[10]PETRŮ, J., ZLÁMAL, T., ČEP, R., PAGÁČ, M., GREPL, M. (2013). Influence of strengthening effect on machinability of the welded inconel 625 and of the wrought Inconel 625. IMETI 2013 - 6th International MultiConference on Engineering and Technological Innovation, Proceedings, pp.155 - 159. 